\title{
Nivolumab-based immunotherapy in relapsed/refractory B-cell lymphoma, unclassifiable, with features intermediate between diffuse large B-cell lymphoma and classical Hodgkin lymphoma
}

Olesya G. Smykova, Kirill V. Lepik, Natalia B. Mikhailova, Elena V. Kondakova, Evgenia S. Borzenkova, Elena E. Lepik, Yuri R. Zalyalov, Lilia V. Stelmakh, Vadim V. Baykov, Ivan S. Moiseev, Alexander D. Kulagin, Boris V. Afanasyev RM Gorbacheva Research Institute of Pediatric Oncology, Hematology and Transplantation, Pavlov University, St. Petersburg, Russia

Dr. Olesya G. Smykova, RM Gorbacheva Research Institute E-mail: olesya.gen@gmail.com of Pediatric Oncology, Hematology and Transplantation, Pavlov University, Roentgen St. 12, 197022, St. Petersburg, Russia

Citation: Smykova OG, Lepik KV, Mikhailova NB et al. Nivolumab-based immunotherapy in relapsed/refractory B-cell lymphoma, unclassifiable, with features intermediate between diffuse large B-cell lymphoma and classical Hodgkin lymphoma. Cell Ther Transplant 2021; 10(1): 37-43.

\section{Summary}

The treatment of relapsed/refractory gray zone lymphoma ( $r / r$ GZL) remains challenging. Genetic aberrations involving 9p24.1 and associated with programmed death ligand (PD-L1/L2) upregulation are important in GZL pathogenesis and immune evasion. Immune checkpoint inhibitor nivolumab (PD-1-blocking antibody) may be an attractive treatment strategy in GZL. We have retrospectively assessed efficacy and toxicity of nivolumab-based regimens in nine patients with $\mathrm{r} / \mathrm{r}$ GZL. Most of the patients $\mathrm{n}=7$ (78\%) had primary chemoresistance and the median number of prior therapy lines was 3 (range, 2-5). At the start of nivolumab treatment disease stage III-IV was in $n=6(67 \%)$ patients and bulky disease was in $n=3(33 \%)$ patients. All nine patients had high-level of PD-L1 expression (80\%$100 \%)$ on tumor cells. In this group $n=4(44 \%)$ patients received nivolumab as monotherapy, $n=3$ (33\%) received nivolumab in combination with chemotherapy, $\mathrm{n}=1(11 \%)$ received nivolumab in combination with $\mathrm{BV}$ and $n=1(11 \%)$ received nivolumab in combination with lenalidomide. The objective response rate among all treated patients was $89 \%$ with 6 cases $(67 \%)$ of complete response and 2 (22\%), with partial response. One patient (11\%) had stabilization of the disease as best response.
Median duration of response was 14 (range 5-26) months. Median follow-up time was 25 months (range, 6-30) from the start of nivolumab-based treatment. Overall survival and progression free survival rates were $83 \%$ and $38 \%$, respectively. This case series demonstrated that nivolumab-based regimen may be an effective treatment option for patients with $\mathrm{r} / \mathrm{r}$ GZL.

\section{Keywords}

Gray-zone lymphoma, relapse, immune checkpoints inhibitors, nivolumab, hematopoietic stem cell transplantation, allogeneic, autologous. 


\section{Introduction}

B-cell lymphoma, unclassifiable, with features intermediate between diffuse large B-cell lymphoma (DLBCL) and classical Hodgkin lymphoma (cHL) was initially described in 1998 [1] and first recognized in the World Health Organization classification as a distinct entity in 2008 [2]. It is a rare and aggressive lymphoma, also known as gray zone lymphoma (GZL), with morphologic and immunophenotypic features overlap with both of primary mediastinal large B-cell lymphoma (PMBL) and cHL, nodular sclerosis [3]. Initially, GZL with mediastinum involvement, i.e., mediastinal GZL (MGZL), was described, whereas data on non-mediastinal GZL (NMGZL) were obtained later. MGZL typically occurs in young adults. In contrast, patients with NMGZL are usually older, with advanced-stage disease and extranodal involvement. However, a large retrospective study in the North American population with 112 cases of GZL demonstrated that the patients with MGZL and NMGZL have similar outcomes [4].

GZL shows a wide variety of morphological features and can be represented by tumor cells cytologically related to $\mathrm{cHL}$ (cHL-like GZL), but with large B-cell lymphoma (LBCL) immunophenotype (CD20, CD79a, PAX5, and OCT2), while another type of GZL can demonstrate large B-cell lymphoma morphology (LBCL-like GZL) with cHL immunophenotype (CD15 and CD30). Similar to CHL and PMBL, genetic alterations involving CIITA (16p13.13) and CD274 (PD-L1)/PDCD1LG2 (PD-L2) (9p24.1) have been described in GZL [5]. Epigenetic profile of GZL demonstrated close relationship of GZL with CHL/PMBL and the difference between GZL and DLBCL [6].

Due to relative rarity, difficult diagnosis and lack of randomized trials, clinical management of GZL is challenging. There is no standard for a frontline therapy for GZL, but regimens for aggressive large $\mathrm{B}$-cell lymphoma (CHOP +/$\mathrm{R}, \mathrm{EPOCH}, \mathrm{DA}-\mathrm{EPOCH}+/-\mathrm{R}$, etc.) are preferable with consideration for consolidative radiotherapy for bulk disease [4, 7]. GZL has a worse prognosis than either $\mathrm{cHL}$, or PMBL. Compared to PMBL treated with R-DA-EPOCH, the GZL outcomes were significantly lower with 5 -year overall survival (OS) $74 \%$ vs $97 \%$ and 5- year event-free survival (EFS) of $62 \%$ vs $93 \%$, respectively $[8,9]$. About $59 \%$ of patients achieved a complete response, but $33 \%$ had primary refractory disease and $58 \%$ relapsed with a median time to relapse of 7 months [4]. The optimal treatment strategy for relapsed/ refractory $(\mathrm{r} / \mathrm{r})$ GZL is not yet established. Most of the patients received standard salvage chemotherapy and, in case of chemosensitivity, autologous hematopoietic stem cell transplant (HSCT) can be performed. Two-year OS for patients with $\mathrm{r} / \mathrm{r}$ GZL who underwent HSCT was $88 \%$ versus $67 \%$ for the patients who did not undergo HSCT [4]. However, some patients cannot be candidates for high-dose chemotherapy with HSCT due to age, comorbidity, or chemoresistant disease.

As based on biological characteristics of GZL, search for novel target and immunotherapy is necessary. Most cases of GZL show expression of CD30 [8]. Brentuximab vedotin (BV) is an anti-CD30 antibody-drug conjugate that is effective in HL and some T-cell lymphomas. Due to the expression of CD30 in GZL, BV is an attractive treatment strategy in patients with GZL and some data on BV therapy in patients with GZL have been published [10].

Genetic aberrations involving 9p24.1 and associated with programmed death ligand (PD-L1/L2) upregulation are important in GZL pathogenesis and immune evasion [11]. Only case series of patients with $\mathrm{r} / \mathrm{r}$ GZL with complete and durable responses after checkpoint inhibitor treatment were published $[12,13]$. In this view, immune checkpoint inhibitor nivolumab (PD-1-blocking antibody) may be an attractive treatment strategy in GZL.

\section{Patients and methods}

The single-center study included nine patients (6 men and 3 women) with histologically confirmed GZL, relapsed or refractory to at least 2 lines of previous therapy, and treated in RM Gorbacheva Research Institute of Pediatric Oncology, Hematology and Transplantation, Pavlov University. All the patients had active disease following the previous therapy. Patients received nivolumab in dose of $0.5-3 \mathrm{mg} / \mathrm{kg}$ every 2 weeks as monotherapy or in combination with lenalidomide or chemotherapy. Total-body PET/CT scans were performed before treatment initiation, and clinical response was assessed by investigators using LYmphoma Response to Immunomodulatory therapy Criteria (LYRIC) every 3 months. Treatment toxicity was graded according to the Common Terminology Criteria for Adverse Events (CTCAE) v 4.03.

The primary efficacy endpoint was the overall response rate during nivolumab therapy, defined as the proportion of patients with complete response (CR) or partial response (PR) in measurable lesions by LYRIC criteria within a timeframe of 24 months. The efficacy and safety evaluable population included those patients who received at least 1 cycle of therapy. To evaluate the best response, all assessments during therapy were analyzed up to the treatment discontinuation or initiation of other therapy. Secondary endpoints included frequency of grade 3 or higher treatment-related adverse events by NCI CTCAE 4.03, duration of response (DOR), progression-free survival (PFS) and overall survival (OS). Duration of response was defined as the time from initial objective response to documented disease progression or death; PFS was defined as the time from the first nivolum$\mathrm{ab}$ infusion to disease progression, relapse or death; overall survival (OS) defined as the time from the first nivolumab infusion to death from any reason. In each survival outcome, data were censored at the date of last contact for patients who have not experienced the events of interest during their follow-up. Both OS and PFS were censored at the date of last contact and were estimated using Kaplan-Meier method with 95\% CI estimates. All analyses were performed using SPSS system v 17.0 and R 3.6.1 software.

\section{Results}

\section{Therapeutic effects of nivolumab-containing treatment schedules}

All the patients $(n=9)$ were included into safety and efficacy analysis. The median age was $35(23-87)$ years. Six patients 
(67\%) were initially diagnosed as cHL, one patient (11\%), as PMBL, and two patients, as GZL (22\%). Thus, 6 patients at the first-line therapy received regimens for $\mathrm{CHL}$ (ABVD, BEACOPP), and 3 patients were treated with regimens for aggressive large B-cell lymphoma (R-CHOP, R-DA-EP$\mathrm{OCH})$. Most patients $(\mathrm{n}=7,78 \%)$ had primary chemoresistance and the median number of prior therapy lines was 3 (range, 2-5). At the start of nivolumab treatment, the disease stage III-IV was assessed in 6 cases (67\%), and bulky disease was registred in 3 patients (33\%).

All nine patients showed high levels of PD-L1 expression (80\%-100\%) on their tumor cells. In this group, 4 patients (44\%) received nivolumab as monotherapy, 3 patients (33\%) received nivolumab in combination with chemotherapy, one patient $(11 \%)$ was treated with nivolumab in combination with BV, and nivolumab in combination with lenalidomide was used in one case (11\%). Demographic characteristics and clinical data are summarized in Table 1.

Median follow-up time was 25 months (range, 6-30) from the start of nivolumab-based treatment. Objective response rate among all the treated patients was $89 \%$, with complete response (CR) in 6 cases (67\%), and partial response (PR) in 2 cases $(22 \%)$. One patient $(11 \%)$ had shown stabilization of the disease as best response. Median duration of response (DOR) was 14 months (range 5-26). After immunotherapy, one patient in CR underwent allogeneic hematopoietic stem cell transplantation (allo-HSCT) from haploidentical donor, and 3 patients in $\mathrm{CR}$ underwent autologous hematopoietic stem cell transplantation (auto-HSCT) as the consolidation treatment. One patient after allo-HSCT and two patients

Table 1. Demographic and clinical characteristics of the studied GZL patients

\begin{tabular}{|c|c|c|c|c|c|c|c|c|c|c|}
\hline Patients, no & 1 & 2 & 3 & 4 & 5 & 6 & 7 & 8 & 9 & Summary \\
\hline Gender & Male & Female & Male & Male & Male & Male & Female & Male & Female & $\begin{array}{l}\text { Male } n=6(67 \%) \\
\text { Female } n=3(33 \%)\end{array}$ \\
\hline Age & 23 & 38 & 87 & 35 & 31 & 27 & 41 & 31 & 64 & Median 35 (23-87) \\
\hline $\begin{array}{l}\text { Initially } \\
\text { diagnosis }\end{array}$ & $\mathrm{CHL}$ & $\mathrm{CHL}$ & $\mathrm{CHL}$ & $\mathrm{CHL}$ & $\mathrm{CHL}$ & $\mathrm{CHL}$ & PMBL & GZL & GZL & $\begin{array}{l}\text { cHL } n=6(67 \%) \\
\text { PMBL } n=1(11 \%) \\
\text { GZL } n=2(22 \%)\end{array}$ \\
\hline $\begin{array}{l}\text { First-line } \\
\text { therapy }\end{array}$ & BEACOPP & ВЕАСОРP & ABVD & ABVD & BEACOPP & ВЕАСОРР & R-CHOP & R-DA-EPOCH & $\mathrm{R}-\mathrm{CHOP}$ & $\begin{array}{l}\text { cHL-like regimen } \\
\mathrm{n}=6 \text { (67\%) } \\
\text { DLBCL- like regi- } \\
\text { men } n=3(33 \%)\end{array}$ \\
\hline $\begin{array}{l}\text { Primary } \\
\text { chemore- } \\
\text { sistance }\end{array}$ & Yes & Yes & No & Yes & Yes & Yes & No & Yes & No & $n=6(67 \%)$ \\
\hline $\begin{array}{l}\text { Number of } \\
\text { prior thera- } \\
\text { py lines }\end{array}$ & 4 & 4 & 3 & 2 & 2 & 2 & 3 & 5 & 2 & Median $3(2-5)$ \\
\hline $\begin{array}{l}\text { Auto-HSCT } \\
\text { before Nivo }\end{array}$ & No & Yes & No & No & No & No & No & No & No & $n=1(11 \%)$ \\
\hline $\begin{array}{l}\text { B-symptoms } \\
\text { at the start } \\
\text { of treatment } \\
\text { with Nivo }\end{array}$ & Yes & Yes & Yes & Yes & Yes & No & Yes & No & No & $n=6(67 \%)$ \\
\hline $\begin{array}{l}\text { Stage at } \\
\text { the start of } \\
\text { treatment } \\
\text { with Nivo }\end{array}$ & IV & IV & IV & III & IV & II & IV & II & II & $\begin{array}{l}\text { II n=3 (33\%) } \\
\text { III-IV n=6 (67\%) }\end{array}$ \\
\hline $\begin{array}{l}\text { Bulky } \\
\text { disease }\end{array}$ & Yes & No & No & No & Yes & No & Yes & No & No & $n=3$ (33\%) \\
\hline $\begin{array}{l}\text { PD-L1 } \\
\text { expression }\end{array}$ & $100 \%$ & $90 \%$ & $100 \%$ & $90 \%$ & $100 \%$ & $100 \%$ & $80 \%$ & $100 \%$ & $100 \%$ & $\begin{array}{l}\text { Median } 100 \% \\
(80-100)\end{array}$ \\
\hline $\begin{array}{l}\text { Nivolumab- } \\
\text { based ther- } \\
\text { apy }\end{array}$ & $\begin{array}{l}\text { Nivo + } \\
\text { BV }\end{array}$ & $\begin{array}{l}\text { Mono- } \\
\text { Nivo }\end{array}$ & $\begin{array}{l}\text { Mono- } \\
\text { Nivo }\end{array}$ & $\begin{array}{l}\text { Mono- } \\
\text { Nivo }\end{array}$ & $\begin{array}{l}\text { Nivo }+ \\
\text { Chemo }\end{array}$ & $\begin{array}{l}\text { Nivo }+ \\
\text { Chemo }\end{array}$ & $\begin{array}{l}\text { Mono- } \\
\text { Nivo }\end{array}$ & Nivo + Len & $\begin{array}{l}\text { Nivo }+ \\
\text { Chemo }\end{array}$ & $\begin{array}{l}\text { Mono-Nivo } \mathrm{n}=4 \\
(44 \%) \\
\text { Nivo + Chemo n=2 } \\
(22 \%) \\
\text { Nivo +BV n=1 (11\%) } \\
\text { Nivo + Len } \mathrm{n}=1 \\
(11 \%) \\
\end{array}$ \\
\hline $\begin{array}{l}\text { Nivolumab } \\
\text { dose, mg/kg }\end{array}$ & 3 & 3 & 0.5 & 3 & 0,5 & 0.5 & 3 & 1 & 0.5 & Median $1(0.5-3)$ \\
\hline
\end{tabular}


after auto-HSCT are alive in CR. Another patient after autoHSCT relapsed and was re-treated with nivolumab combined with brentuximab vedotin, followed by CR achievement. Overall, 4 patients received additional therapy after nivolumab-based treatment, due to disease progression. At the time of analysis, 6 patients are alive and in CR, one patient is alive in PR (proceeding with nivolumab therapy), one patient is alive in progression (receiving another therapy), and one patient died, due to the disease progression. Overall survival and progression-free survival rates were $83 \%$ and $48 \%$, respectively. Clinical outcomes are presented in Table 2 and Fig. 1, 2.

\section{Nivolumab toxicity}

During nivolumab treatment, 3 (33\%) patients experienced grade 3-4 adverse events (AEs), which included two cases of neutropenia (these two patients received nivolumab in combination with chemotherapy) and one case of autoimmune pneumonitis. Due to severe adverse events, nivolumab treatment was discontinued, and the patient received glucocorticoids ( $1 \mathrm{mg} / \mathrm{kg}$ methylprednisolone) with complete resolution of pneumonitis.

Table 2. Clinical complications and outcomes in the studied lymphoma patients

\begin{tabular}{|l|l|l|l|l|l|l|l|l|l|}
\hline Patients, no & $\mathbf{1}$ & $\mathbf{2}$ & $\mathbf{3}$ & $\mathbf{4}$ & $\mathbf{5}$ & $\mathbf{6}$ & $\mathbf{7}$ & $\mathbf{8}$ & $\mathbf{9}$ \\
\hline Best response & CR & CR & SD & PR & CR & CR & PR & CR & CR \\
\hline AEs 3-4 grade & No & $\begin{array}{l}\text { Autoimmune } \\
\text { pneumonitis }\end{array}$ & No & No & Neutropenia & Neutropenia & No & No & No \\
\hline $\begin{array}{l}\text { Consolidation } \\
\text { with HSCT }\end{array}$ & Allo & No & No & No & Auto & Auto & No & Auto & No \\
\hline $\begin{array}{l}\text { Relapse/ } \\
\text { progression }\end{array}$ & No & No & Yes & Yes & No & No & No & Yes & Yes \\
\hline $\begin{array}{l}\text { Nivolumab } \\
\text { retreatment }\end{array}$ & No & No & $\begin{array}{l}\text { No, } \\
\text { another } \\
\text { therapy }\end{array}$ & $\begin{array}{l}\text { No, } \\
\text { another } \\
\text { therapy }\end{array}$ & No & No & $\begin{array}{l}\text { Continues } \\
\text { Nivo }\end{array}$ & $\begin{array}{l}\text { Nivo + } \\
\text { BV }\end{array}$ & $\begin{array}{l}\text { No, } \\
\text { another } \\
\text { therapy }\end{array}$ \\
\hline Current status & CR & CR & PD & PD & CR & CR & PR & CR & CR \\
\hline Alive & Yes & Yes & Yes & No & Yes & Yes & Yes & Yes & Yes \\
\hline $\begin{array}{l}\text { Follow up, } \\
\text { months }\end{array}$ & 30 & 27 & 25 & 12 & 27 & 11 & 6 & 30 & 9 \\
\hline
\end{tabular}

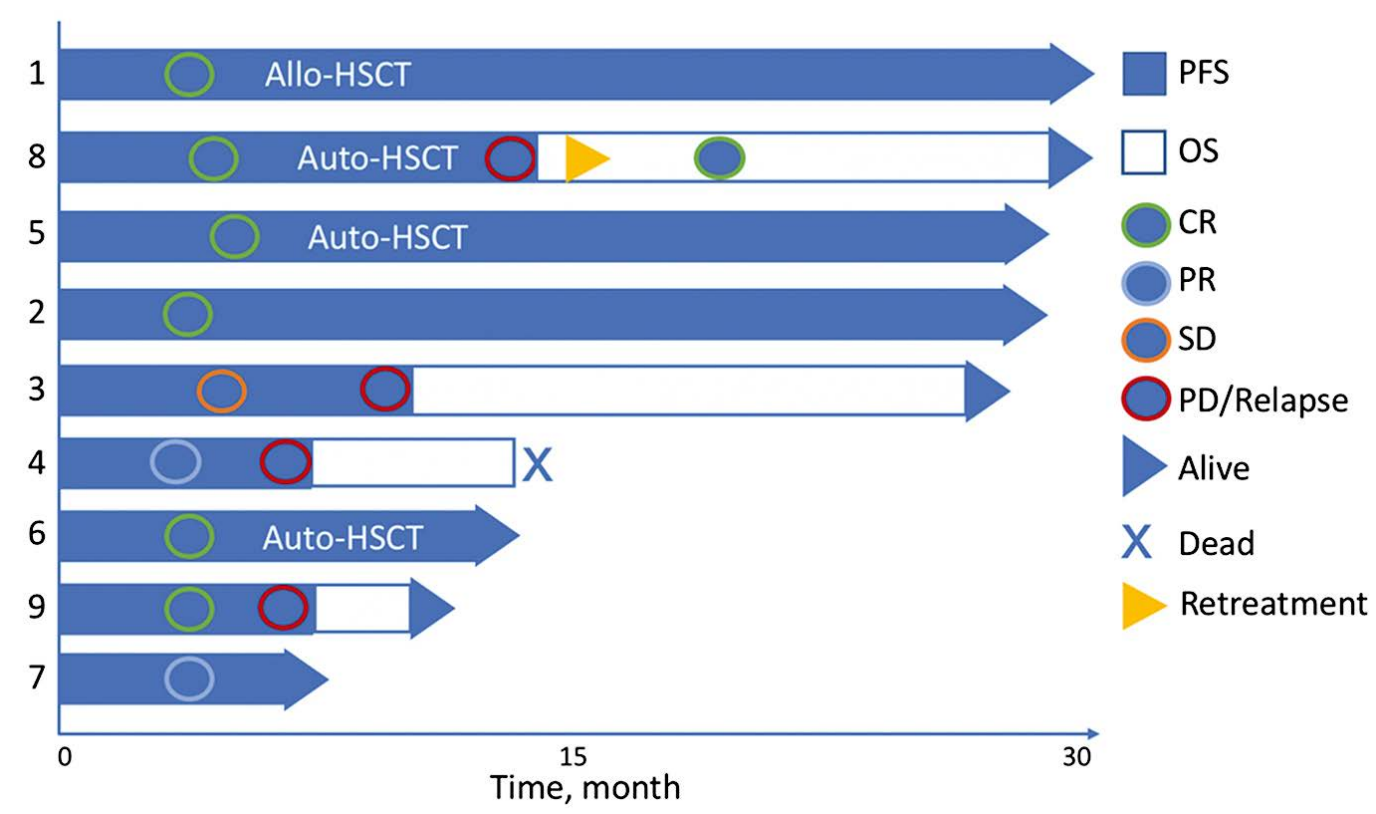

\section{Figure 1. Characteristics of clinical response achieved during observation period}

Numbers of the left ordinate axis represent the patient number (see Table 1 and Table 2), OS, overall survival; PFS, progression-free survival; CR, complete remission achieved; PR, partial remission achieved; PD/Relapse, time point of documented progression or relapse; Retreatment, time point of starting repeated nivolumab treatment. 
(A)

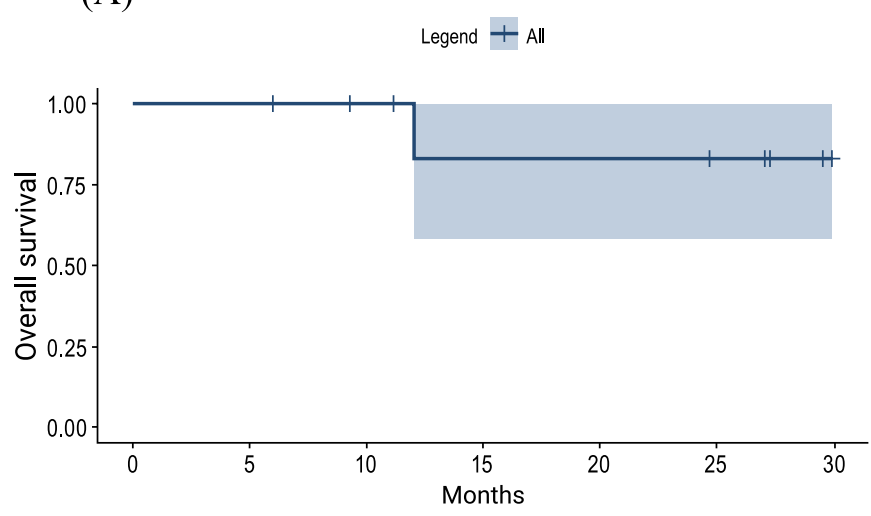

Number at risk
(B)

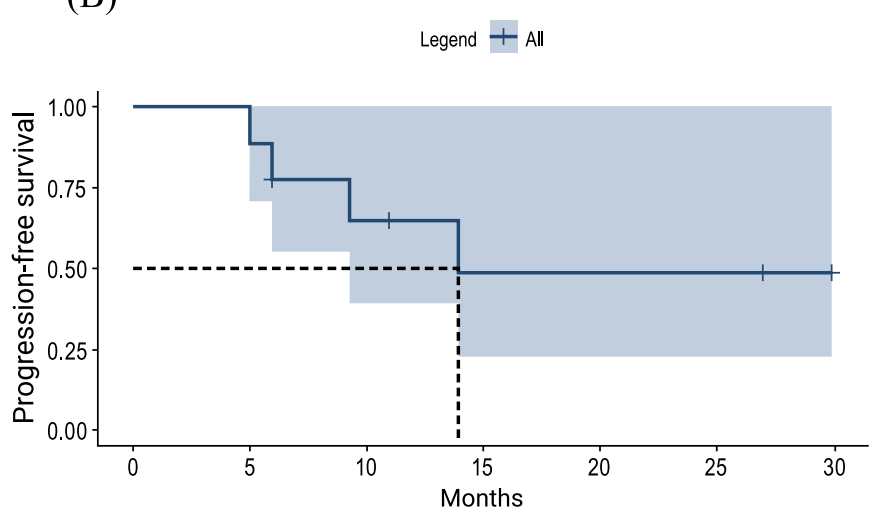

Number at risk

$\begin{array}{rlllllllllllll}-9 & 9 & 7 & 5 & 5 & 4 & 1 & - & 9 & 9 & 5 & 3 & 3 & 3\end{array}$

Figure 2. Two-year overall survival (A) and progression-free survival (B) for the patients with $r / r$ GZL after nivolumab-based treatment

\section{Discussion}

The diagnosis of GZL is difficult, due to clinical, morphological and immunophenotypic features [14,15]. In our study, only 2 of 9 patients were initially diagnosed with GZL, while 6 patients were diagnosed as classical Hodgkin's lymphoma (cHL). This group of patients received cHL-like regimens (ABVD or BEACOPP), as frontline therapy. However, dose-intensive chemotherapy might be more effective in GZL, and 5 of 6 patients who received cHL-like regimen showed primary chemoresistance. Retrospective study of the 112 patients with GZL who received ABVD, R-CHOP or R-DA-EPOCH, as frontline therapy, demonstrated significantly inferior PFS rate for the patients treated with ABVD versus DLBCL-based regimen with two-year rates of $23 \%$ versus $52 \%$, respectively. In patients with chemosensitive $\mathrm{r} / \mathrm{r}$ GZL, high-dose chemotherapy with auto-HSCT may be beneficial [4]. However, in patients with chemoresistant disease, the optimal treatment strategy is not well established, and there are only scarce clinical data on usage of biological agents for $\mathrm{r} / \mathrm{r}$ GZL.

GZL share a common genetic signature and high rates of 9p24.1 gain, similar to cHL. Blockade of PD-1/PD-L1 pathway demonstrated beneficial therapeutic effect in cHL patients $[16,17]$, but there is limited data on effects of checkpoint inhibitors in GZL. In our study, all 9 patients initially demonstrated high-level (80\%-100\%) PD-L1 expression. Depending on the stage of the disease, patients received nivolumab at different regimens, i.e., nivolumab as monotherapy, or in combination with other drugs (lenalidomide, $\mathrm{BV}$, chemotherapy), dose of nivolumab was $0.5-3 \mathrm{mg} / \mathrm{kg}$. Decrease of tumor mass was noted in all patients during nivolumab-based therapy, with objective response in 8 of 9 patients, regardless of nivolumab regimen and dose. However, an elderly patient ( 87 y.o.) who achieved only stabilization of the disease, well tolerated the nivolumab therapy, showing suppression of tumor growth and good quality of life.

BV may augment the effect of PD-1 blockade, and combination of nivolumab with BV demonstrated efficacy in $\mathrm{r} / \mathrm{r} \mathrm{cHL}$
[18]. In this study, 2 patients received nivolumab with BV, one of them relapsed after earlier nivolumab treatment. Both patients achieved CR after this treatment. Thus, nivolumab with $\mathrm{BV}$ may be perspective treatment option for the patients with $\mathrm{r} / \mathrm{r}$ GZL. Moreover, among 8 patients with objective response to nivolumab-based treatment, four patients received hematopoietic stem cell transplantation as the consolidation of response. Thus, nivolumab can be used as a "bridge" to HSCT.

\section{Conclusion}

Diagnosis and treatment of GZL still represent a challenge to clinicians. This case series demonstrated that nivolumab-based regimen may be an effective treatment option for patients with $\mathrm{r} / \mathrm{r}$ GZL. Larger studies of nivolumab therapy and development of optimal combinations of target and immunotherapy for GZL are required in future.

\section{Acknowledgments}

The authors thank the patients as well as research and medical staff for making this study possible.

\section{Financial disclosure}

The authors have nothing to disclose.

\section{Conflict of interest statement}

There are no conflicts of interest to report.

\section{References}

1. Rüdiger T, Jaffe ES, Delsol G, deWolf-Peeters C, Gascoyne RD, Georgii A, et al. Workshop report on Hodgkin's disease and related diseases ('grey zone' lymphoma). Ann Oncol. 1998;9 Suppl 5:S31-8. doi: 10.1093/annonc/9.suppl 5.s31.

2. Swerdlow S, Campo E, Harris N, et al. WHO classification of tumours of haematopoietic and lymphoid tissues. 
$4^{\text {th }}$ edition. Lyon (France): International Agency for Research on Cancer; 2008.

3. Pilichowska M, Pittaluga S, Ferry JA, Hemminger J, Chang H, Kanakry JA, et al. Clinicopathologic consensus study of gray zone lymphoma with features intermediate between DLBCL and classical HL. Blood Adv. 2017;1(26):26002609. doi: 10.1182/bloodadvances.2017009472.

4. Evens AM, Kanakry JA, Sehn LH, Kritharis A, Feldman T, Kroll A, et al. Gray zone lymphoma with features intermediate between classical Hodgkin lymphoma and diffuse large B-cell lymphoma: characteristics, outcomes, and prognostication among a large multicenter cohort. Am J Hematol. 2015; 90(9):778-783. doi: 10.1002/ajh.24082.

5. Sarkozy C, Copie-Bergman C, Damotte D, Ben-Neriah S, Burroni B, Cornillon J, et al. Gray-zone Lymphoma Between cHL and Large B-Cell Lymphoma: A Histopathologic Series From the LYSA. Am J Surg Pathol. 2019; 43(3):341-351. doi: 10.1097/PAS.0000000000001198.

6. Eberle FC, Rodriguez-Canales J, Wei L, Hanson JC, Killian JK, Sun HW, et al. Methylation profiling of mediastinal gray zone lymphoma reveals a distinctive signature with elements shared by classical Hodgkin's lymphoma and primary mediastinal large B-cell lymphoma. Haematologica. 2011; 96(4):558-566. doi: 10.3324/haematol.2010.033167.

7. Chihara D, Westin JR, Miranda RN, Cheah CY, Oki Y, Turturro F, et al. Dose adjusted-EPOCH-R and mediastinal disease may improve outcomes for patients with grayzone lymphoma. Br J Haematol. 2017;179(3):503-506. doi: 10.1111/bjh.14226.

8. Dunleavy K, Wilson WH. Primary mediastinal B-cell lymphoma and mediastinal gray zone lymphoma: do they require a unique therapeutic approach? Blood. 2015; 125(1):33-9. doi: 10.1182/blood-2014-05-575092.

9. Wilson WH, Pittaluga S, Nicolae A, Camphausen K, Shovlin M, Steinberg SM, Roschewski M, et al. A prospective study of mediastinal gray-zone lymphoma. Blood. 2014; 124(10):1563-1569. doi: 10.1182/blood-2014-03-564906.

10. Jacobsen ED, Sharman JP, Oki Y, Advani RH, Winter JN, Bello CM, et al. Brentuximab vedotin demonstrates objective responses in a phase 2 study of relapsed/refractory DLBCL with variable CD30 expression. Blood. 2015;125(9):13941402. doi: 10.1182/blood-2014-09-598763.

11. Eberle FC, Salaverria I, Steidl C, Summers TA Jr, Pittaluga S, Neriah SB, et al. Gray zone lymphoma: chromosomal aberrations with immunophenotypic and clinical correlations. Mod Pathol. 2011; 24(12):1586-1597. doi: 10.1038/ modpathol.2011.116.

12. Melani C, Major A, Schowinsky J, Roschewski M, Pittaluga S, Jaffe ES, et al. PD-1 Blockade in Mediastinal GrayZone Lymphoma. N Engl J Med. 2017; 377(1):89-91. doi: $\underline{10.1056 / N E J M c 1704767 . ~}$

13. Rosales YMZ, Mesquita JL, Garcia YDO, Paz FRF, Campos NCB, de Vasconcelos Leitão JP, et al. Use of checkpoint inhibitors in gray zone lymphoma. Hematol Oncol Stem Cell Ther. 2020:S1658-3876(20)30112-6. doi: 10.1016/j. hemonc.2020.06.001.
14. Misyurina AE, Kravchenko SK, Mangasarova YK, et al. Gray-zone lymphoma. Examples of rare clinical manifestation. Therapeutic Archive. 2019; 91 (4): 107-113. doi: 10.264 42/00403660.2019.04.000071.

15. Kovrigina AM, Probatova NA. Hodgkin's lymphoma and large cell lymphomas. Moscow: MIA Publ.; 2007 (In Russian).

16. Armand P, Engert A, Younes A, Fanale M, Santoro A, Zinzani PL, et al. Nivolumab for relapsed/refractory classic Hodgkin lymphoma after failure of autologous hematopoietic cell transplantation: Extended follow-up of the multicohort Single-Arm Phase II CheckMate 205 Trial. J Clin Oncol. 2018; 36(14):1428-1439. doi: 10.1200/JCO.2017.76.0793.

17. Lepik KV, Mikhailova NB, Moiseev IS, Kondakova EV, Tsvetkova LA, Zalyalov YR, et al. Nivolumab for the treatment of relapsed and refractory classical Hodgkin lymphoma after ASCT and in ASCT-naïve patients. Leuk Lymphoma. 2019; 60(9):2316-2319. doi: 10.1080/10428194.2019.1573368.

18. Herrera A, Moskowitz A, Bartlett N, Vose JM, Ramchandren R, Feldman TA, LaCasce AS, Ansell SM, Moskowitz $\mathrm{CH}$, Fenton $\mathrm{K}$, et al. Interim results of brentuximab vedotin in combination with nivolumab in patients with relapsed or refractory Hodgkin lymphoma. Blood 2018;131:1183-1194. doi: 10.1182/blood-2017-10-811224. 


\section{Иммунотерапия на основе ниволумаба при рецидивирующей/рефрактерной В-клеточной лимфоме, неклассифициируемой, с промежуточными признаками между диффузной крупноклеточной В-лимфомой и классической лимфомой Ходжкина}

Олеся Г. Смыкова, Кирилл В. Лепик, Наталья Б. Михайлова, Елена В. Кондакова, Евгения С. Борзенкова, Елена Е. Лепик, Юрий Р. Залялов, Лилия В. Стельмах, Вадим В. Байков, Иван С. Моисеев, Александр Д. Кулагин, Борис В. Афанасьев

НИИ детской онкологии, гематологии и трансплантологии им. Р. М. Горбачевой, Первый Санкт-Петербургский государственный медицинский университет им. акад. И. П. Павлова, Санкт-Петербург, Россия

\section{Резюме}

Терапия рецидивирующей/рефрактерной лимфомы серой зоны (p/p ЛС3) остается сложной задачей. Генетические аберрации с участием 9p24.1 и связанные с активацией лиганда запрограммированной клеточной гибели (PD-L1/L2) важны в патогенезе ЛС3 и уклонении опухолевых клеток от иммунитета. Применение ингибитора иммунных контрольных точек - ниволумаба (антитело, блокирующее PD-1) может быть привлекательной стратегией в терапии ЛСЗ. Мы ретроспективно оценили эффективность и токсичность схем на основе ниволумаба у девяти пациентов с p/p ЛСЗ. Большинство пациентов $\mathrm{n}=7$ (78\%) имели первичную химиорезистентность, медиана предшествующих линий терапии составила 3 линии (диапазон от 2 до 5 линий). На момент начала терапии ниволумабом III-IV стадия заболевания была у $\mathrm{n}=6$ (67\%) пациентов, а объемное образование у $\mathrm{n}=3$ (33\%) пациентов. У всех девяти пациентов был высокий уровень экспрессии PD-L1 (80\%-100\%) на опухолевых клетках. В этой группе $\mathrm{n}=4$ (44\%) пациента получили ниволумаб в монотерапии, $\mathrm{n}=3$ (33\%) - ниволумаб в комбинации с химиотерапией, $\mathrm{n}=1$ (11\%) - ниволумаб в комбинации с брентуксимабом ведотином и $\mathrm{n}=1(11 \%)-$ ниволумаб в сочетании с леналидомидом. Частота объективного ответа среди всех пациентов составила 89\%, у 6 (67\%) пациентов был достигнут полный ответ и 2-х (22\%) пациентов - частичный ответ.
У одного пациента (11\%) стабилизация заболевания была лучшим ответом. Медиана продолжительности достигнутого ответа составила 14 месяцев (диапазон 5-26 месяцев). Медиана времени наблюдения составила 25 месяцев (от 6 до 30 месяцев) от начала терапии ниволумабом. Общая выживаемость и выживаемость без прогрессирования заболевания составили $83 \%$ и $38 \%$, соответственно. Эта серия клинических случаев продемонстрировала, что схемы на основе ниволумаба могут быть эффективным вариантом терапии пациентов с p/p ЛСЗ

\section{Ключевые слова}

Лимфома «серой зоны», рецидив, ингибиторы иммунных точек, ниволумаб, трансплантация гемопоэтических стволовых клеток, аллогенная, аутологичная. 